\title{
Opioid Antagonist (Naltrexone) Modulation of Cerebellar Development: Histological and Morphometric Studies
}

\author{
lan S. Zagon and Patricia J. McLaughlin \\ Department of Anatomy, The Milton S. Hershey Medical Center, The Pennsylvania State University, \\ Hershey, Pennsylvania 17033
}

\begin{abstract}
The role of endogenous opioid systems in preweaning cerebellar development was explored in rats utilizing naltrexone, a potent opioid antagonist. Sprague-Dawley rats were given daily subcutaneous injections of either 1 or $50 \mathrm{mg} / \mathrm{kg}$ naltrexone to invoke a temporary or complete blockade, respectively, of opioid receptors throughout the first 3 weeks of postnatal life; animals injected with sterile water served as controls. At weaning (day 21), macroscopic, morphometric, and histological determinations were conducted. In general, $50 \mathrm{mg} / \mathrm{kg}$ naltrexone had a stimulatory action on cerebellar development, whereas $1 \mathrm{mg} / \mathrm{kg}$ naltrexone had an inhibitory influence. Both sexes were affected comparahly. Iimits to naltrexone's ability to modulate cerebellar ontogeny were noted, with more latitude existing toward growth enhancement than impairment. The temporal course of ontogeny was generally unaltered in naltrexone-treated rats. Rather, only events that transpired over this period were dramatically affected. The most notable effects in $1 \mathrm{mg} / \mathrm{kg}$ naltrexone rats were marked decreases in cerebellar areal dimensions, the content of internal granule neurons, and cellular and tissue differentiation. Characteristics of the $50 \mathrm{mg} / \mathrm{kg}$ naltrexone group included increases in cerebellar areal dimensions, neural cell number, content, and size, and structural changes consistent with acceleration in growth and differentiation. Naltrexone influenced both neurons and glia, but only neural cells still being generated during the first $21 \mathrm{~d}$ after birth were altered in regard to quantity. Previous evidence has shown the presence of peak levels of endogenous opioids and opioid receptors in the cerebellum during the first weeks of life, as well as demonstrating the presence of enkephalin immunoreactivity on germinative cerebellar cells during postnatal neurogenesis but not in adult counterparts. Our results show that endogenous opioid systems are natural trophic factors in cerebellar growth and serve to document the critical importance of endogenous opioid-opioid receptor interaction in nervous system development.
\end{abstract}

The untoward action of exogenous opioid agonists such as heroin, methadone, and morphine on somatic and neurobiological development of humans and laboratory animals is well documented (Slotkin et al., 1980; Smith et al., 1977; Wilson, 1975; also see Zagon et al., 1982, 1984). In laboratory studies, these growth-altering effects have been demonstrated to be stereospecific and blocked by concomitant administration of opioid antagonists (McLaughlin and Zagon, 1984; Smith et al., 1977). Investigations in our laboratory have documented that opioid antagonists also influence normal growth, as well as neoplasia

Received July 17, 1985; revised Nov. 22, 1985; accepted Nov. 22, 1985.

This work was supported in part by NIH Grants NS-20500 and NS-20623. A preliminary report was presented at the Vth Meeting of the International Society for Developmental Neurobiology, Chieti, Italy, June, 1984.

Correspondence should be addressed to Dr. Zagon at the above address.

Copyright (C) 1986 Society for Neuroscience $0270-6474 / 86 / 051424-09 \$ 02.00 / 0$
(Zagon and McLaughlin, 1983a-c, 1984, 1985a-c). These effects are stereospecific (Zagon and McLaughlin, 1985c), with the duration of opioid receptor blockade determining the outcome of developmental events (Zagon and McLaughlin, 1984). Thus, continuous blockade of opioid receptors each day enhances growth; temporary opioid receptor blockade each day inhibits growth. These results indicate that endogenous opioid systems (i.e., endogenous opioids and opioid receptors) subserve an important function in developmental and tumor biology: regulation of growth (Zagon and McLaughlin, 1983a, b, 1984). Additional information concerning endogenous opioids and growth has recently come from studies (Zagon et al., 1985) showing that enkephalin immunoreactivity was present in germinative cells of the postnatally developing rat cerebellum but not in adult neural cells. These findings indicate further the importance, and special relationships, of endogenous opioid systems to development.

It is known that preweaning rats receiving daily injections of $50 \mathrm{mg} / \mathrm{kg}$ naltrexone, which block the opioid receptor for $24 \mathrm{hr}$ each day, were found to have an increase in body, brain, and organ weights (Zagon and McLaughlin, 1983b, c, 1984, 1985b) and an acceleration in the appearance of physical characteristics and maturation of spontaneous motor and sensorimotor behaviors (Zagon and McLaughlin, 1983c, 1985a). Daily administration of $1 \mathrm{mg} / \mathrm{kg}$ naltrexone, a dosage that only blocked the opioid receptor for 4-6 hr each day, had the opposite action on development. Little is known about the morphological effects involved in opioid antagonist modulation of neurobiological development. Zagon and McLaughlin (1983b) have demonstrated that macroscopic dimensions of the brain and cerebellum of 21 -d-old offspring (sexes combined) chronically exposed to $50 \mathrm{mg} / \mathrm{kg}$ naltrexone were markedly increased from control levels; notable increases in cerebral and cerebellar areas, as well as content of some neural cells in the cerebellum were also recorded.

The purpose of this investigation was to establish more fully the role of endogenous opioid systems in regulating preweaning cerebellar development by perturbing the interaction of endogenous opioids and opioid receptors with an opioid antagonist (i.e., naltrexone). The rat cerebellum presents an opportune region in which to explore neuromorphogenic processes. In the rat, macroneurons such as the Purkinje cells proliferate prenatally, whereas the ontogeny of microneurons (e.g., internal granule cells) is largely confined to the first 3 postnatal weeks (Altman, 1972). Indeed, between birth and day 21, cell number increases from about 6 to 94 million (Zagon and McLaughlin, 1979). Thus, in this study, macroscopic, histological, and morphometric analyses of 21 -d-old rats subjected to temporary (1 $\mathrm{mg} / \mathrm{kg}$ naltrexone) or continuous ( $50 \mathrm{mg} / \mathrm{kg}$ naltrexone) receptor blockade throughout the preweaning period were performed in order to evaluate cerebellar size, cell concentration and distribution, and cellular differentiation. Males and females were examined separately in order to distinguish any sex differences 
that might occur. Our results indicate that endogenous opioid systems are important trophic factors that determine the course of cerebellar neuro-ontogeny.

\section{Materials and Methods}

\section{Animals and drug protocol}

Newborn animals (day 0) from random-bred Sprague-Dawley female rats were culled to eight pups per mother. All animals were housed under standard laboratory conditions as described elsewhere (Zagon and McLaughlin, 1985a, b). Beginning on day 1, pups were given daily subcutaneous injections of either 1 or $50 \mathrm{mg} / \mathrm{kg}$ naltrexone or sterile water (control) until weaning (day 21). Solutions of naltrexone were prepared by dissolving naltrexone hydrochloride (Endo Laboratories, Garden City, NY) in sterile water; dosages are expressed as salts. Rat pups were weighed periodically and appropriate dosage adjustments made.

\section{Histological procedures}

On day 21 , at least six male and six female offspring selected from at least four different litters from each treatment group were weighed, anesthetized with chloral hydrate, and killed by cardiac perfusion with $10 \%$ neutral buffered formalin. Whole brains were removed and immersed in formalin for $3 \mathrm{~d}$. Using an Olympus X-Tr dissecting microscope with an ocular micrometer, macroscopic dimensions of the brain (to be reported in another communication) and cerebellum were recorded. Cerebellar width was determined by measuring the greatest distance parallel to the long folial axis. Cerebella were dissected from the brain stem, by transecting the peduncles as close to the cerebellum as possible, and weighed. Cerebella were then bisected in the midsagittal plane, embedded in polyester wax, and sectioned at $8 \mu \mathrm{m}$. Midsagittal sections were stained with hematoxylin and eosin, gallocyanin, or protargol (Zagon and Lasher, 1977) for histological and morphometric studies.

\section{Morphometric analysis}

Matched sections of the cerebellum were projected (Bausch and Lomb microprojector) at $22 \times$ onto an Apple Graphics Tablet. The boundaries of the entire cerebellum, and molecular (MOL), internal granule (IGL), and medullary (MED) layers were traced and areal measurements recorded and computed by an Apple II Plus computer. All tracings and measurements were made in a "blind" fashion without knowledge as to which group the slide or drawing belonged. For each parameter, $6-$ 15 cerebella/sex/treatment group were utilized. In addition to areal measurements, the depth of the primary fissure was determined by measuring the distance of a perpendicular line extending from the fissure concavity to a tangential line drawn between the surface convexities of lobes 5 and 6 . The width of the MOL of the pyramis was evaluated by measurement (micrometer) of a line perpendicular to the pial surface and extending from the base of the Purkinje cell layer.

Quantitative analysis of cell number, size, and distribution

The concentration (number cells $/ \mathrm{mm}^{2}$ ) and content (total cells/section) of internal granule neurons, neural cells (excluding endothelial cells, Bergmann glia, displaced migrating granule cells and ependymal cells) in the molecular layer, and glial cells in the medullary layer were estimated in histological sections. Cells were counted in the pyramidal lobe (VIII). At least 10 random fields (grid $=0.0064 \mathrm{~mm}^{2}$ ) were recorded at $630 \times$ using hematoxylin-eosin stained sections from cerebella of six to nine rats/sex/treatment group. To calculate the content of cells per tissue section, the total area and the areas of MOL, IGL, and MED layers in the pyramidal lobe were assessed by the morphometric methods described earlier for the entire cerebellum. To estimate cell content in an entire section of the cerebellum, cell concentration in the pyramis was multiplied by areal measurements of the entire cerebellum. The diameter of internal granule neurons in the pyramis was assessed with an ocular micrometer at $630 \times$, and 20 cells per cerebella and at least six cerebella/sex/treatment group were evaluated.

Various parameters concerned with Purkinje neurons in the pyramidal lobe were analyzed using the procedures of Nicholson and Altman (1972), Barnes and Altman (1973), and Bauer-Moffett and Altman (1977). Purkinje cells having distinct nucleoli were counted blindly at $400 \times$ in

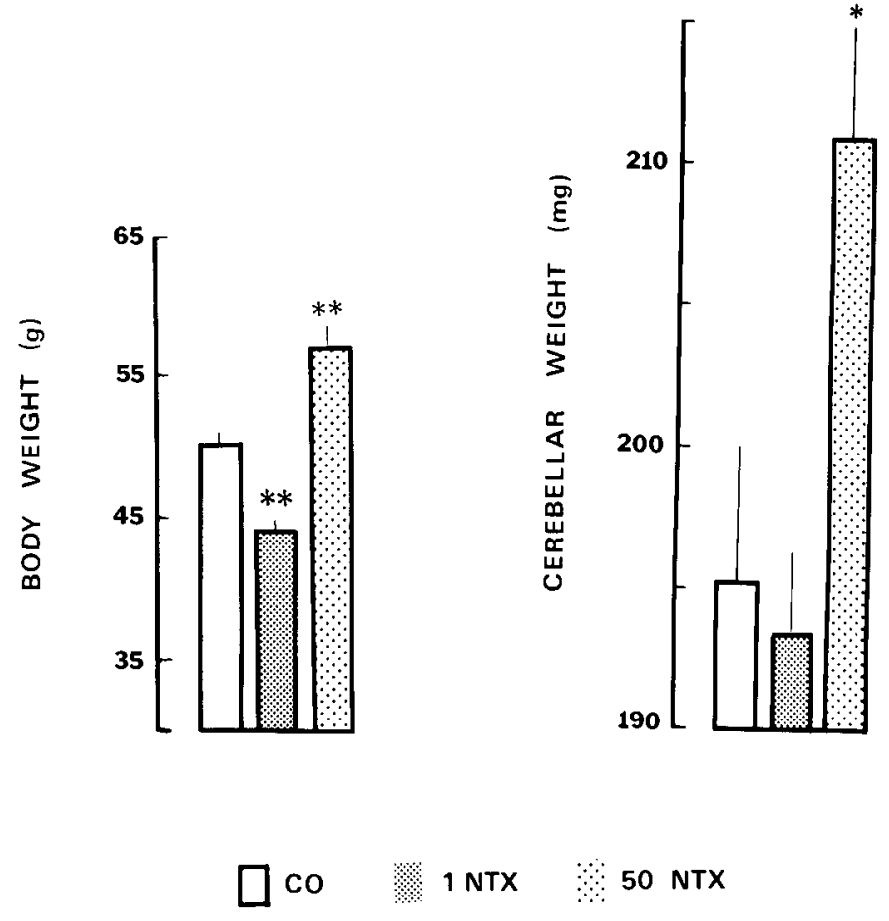

Figure 1. Brain and cerebellar weights of $21-\mathrm{d}$-old rats subjected to daily injections of 1 or $50 \mathrm{mg} / \mathrm{kg}$ naltrexone, or sterile water, throughout preweaning development. Bar indicates SEM. Significantly different from controls at $p<0.05\left(^{*}\right)$ or $p<0.01\left(^{* *}\right)$.

sections from at least six rats/sex/treatment group. The length of the Purkinje cell layer in each section of lobule VIII was measured with an Apple Graphics Tablet and Apple II Plus computer. The number of Purkinje cells per section was then divided by length of the Purkinje cell layer examined in order to obtain "Purkinje cell packing density." The "area of the average Purkinje cell domain" was calculated by dividing the molecular area by the number of Purkinje cells. Purkinje cell width was determined by measuring (micrometer) the diameter of 30 Purkinje cells having distinct nucleoli in the pyramidal lobe per cerebellum; at least six cerebella/sex/treatment group were recorded.

\section{Statistical analysis}

All data were analyzed using the Stats-Plus and ANOVA II programs adapted for the Apple II computer. A two-factor analysis of variance with Treatment Group and Sex as independent variables was used. Subsequent planned comparisons were performed using Newman-Keuls tests. Because the Sex $\times$ Treatment effect was usually consistent for each sex within a treatment group, sexes were combined, and data represent means for the entire treatment group. Sex effects that were prominent are noted in the text.

\section{Results}

\section{Body weights and macroscopic observations}

In concert with our earlier observations (Zagon and McLaughlin, 1983c, 1984, 1985a, b), the body weights of rats of the $50 \mathrm{mg} / \mathrm{kg}$ naltrexone group were significantly increased $(14 \%)$ from control values at $21 \mathrm{~d}$, whereas rats in the $1 \mathrm{mg} / \mathrm{kg}$ naltrexone group weighed markedly less (13\%) than their control counterparts (Fig. 1). Cerebellar weights (Fig. 1) for the $1 \mathrm{mg}$ / $\mathrm{kg}$ naltrexone group were comparable to control levels, but increases of $8 \%$ were recorded in the $50 \mathrm{mg} / \mathrm{kg}$ naltrexone group. Measurements of cerebellar width revealed a $4 \%$ increase $(p<$ 0.01 ) in animals of the $50 \mathrm{mg} / \mathrm{kg}$ naltrexone group, while rats in the $1 \mathrm{mg} / \mathrm{kg}$ naltrexone group did not differ from control levels. 
TOTAL

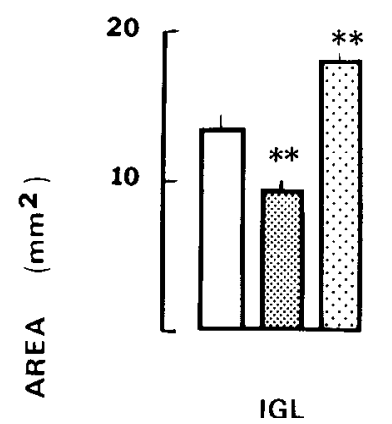

لَّ
MOL

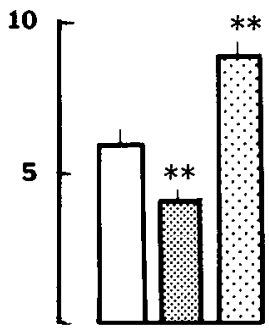

MED

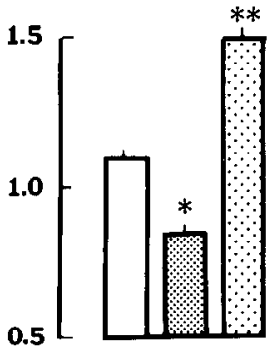

1 NTX

50 NTX
Figure 2. Areal measurements of midsagittal sections of the cerebellum from 2l-d-old rats receiving 1 or $50 \mathrm{mg} / \mathrm{kg}$ naltrexone, or sterile water, during the preweaning period. Bar indicates SEM. Significantly different from controls at $p<0.05\left(^{*}\right)$ or $p<0.01$ (**). $^{* *}$

\section{Morphometric analysis}

In general, animals subjected to $1 \mathrm{mg} / \mathrm{kg}$ naltrexone were often subnormal in regard to morphometric dimensions, while rats that received $50 \mathrm{mg} / \mathrm{kg}$ naltrexone displayed notable increases. Because the trends were similar for both sexes within a treatment group, and for ease of presentation, data are presented as group means.

Results from morphometric assessment of the area of the entire cerebcllum, as well as the areas of the MOL, IGL, and MED layer of 21-d-old rats subjected to naltrexone during the preweaning period, are presented in Figure 2 and illustrated in Figure 3. Marked decreases from control values in these dimensions, ranging from 25 to $29 \%$, occurred for rats given 1 $\mathrm{mg} / \mathrm{kg}$ naltrexone. Significant increases from controls, ranging
TOTAL

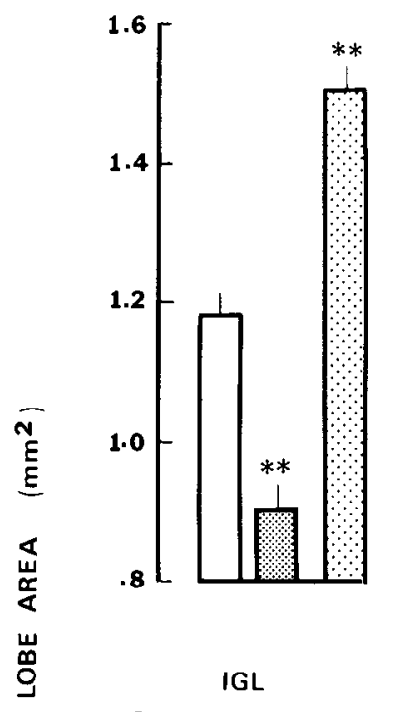

MOL

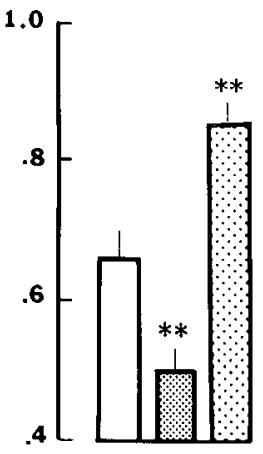

MED

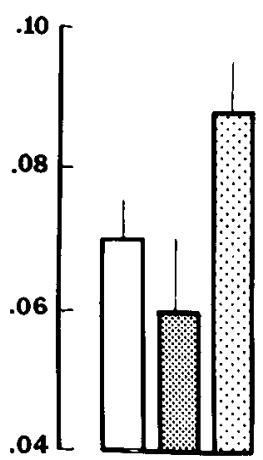

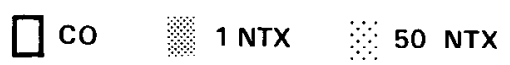

Figure 4. Areal measurements of the pyramidal lobe from cerebella of 21 -d-old rats given 1 or $50 \mathrm{mg} / \mathrm{kg}$ naltrexone, or sterile water, during the preweaning period. Bar indicates SEM. Significantly different from controls at $p<0.05\left(^{*}\right)$ and $p<0.01\left(^{* *}\right)$.

from 27 to $42 \%$, were noted in animals of the $50 \mathrm{mg} / \mathrm{kg}$ naltrexone group. Evaluation of the depth of the primary fissure revealed a marked decrease (7\%) from control levels for animals of the $1 \mathrm{mg} / \mathrm{kg}$ naltrexone group, and a significant increase (14\%) in rats of the $50 \mathrm{mg} / \mathrm{kg}$ naltrexone group.

Figure 3. Camera lucida drawings of midsagittal sections of the cerebellum from 21 -d-old rats that received sterile water $(A)$ or naltrexone at dosages of $1 \mathrm{mg} / \mathrm{kg}(B)$ or $50 \mathrm{mg} / \mathrm{kg}(C)$. Shaded area indicates internal granule layer.

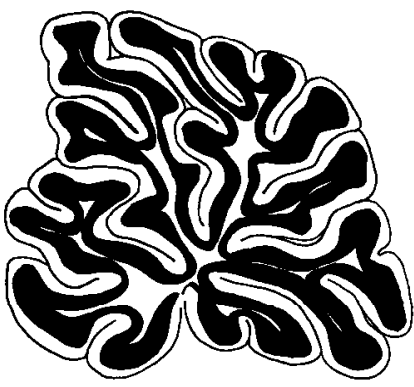

A

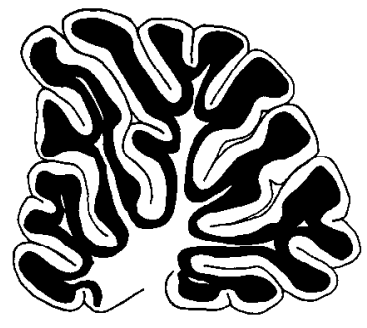

B

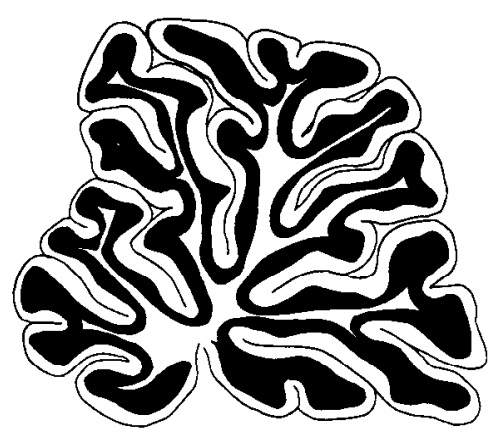

C
$2 \mathrm{~mm}$ 
Table 1. Cell concentration, content, size, and distribution in sagittal sections of the pyramis and total cerebellum of 21 -d-old rats receiving naltrexone during the first 3 weeks of life

\begin{tabular}{|c|c|c|c|}
\hline \multirow[b]{2}{*}{ Layer } & \multirow[b]{2}{*}{ Control } & \multicolumn{2}{|l|}{ Naltrexone } \\
\hline & & $1 \mathrm{mg} / \mathrm{kg}$ & $50 \mathrm{mg} / \mathrm{kg}$ \\
\hline \multicolumn{4}{|l|}{ Molecular } \\
\hline Neural cell concentration, pyramis & $2628 \pm 149$ & $3305 \pm 348$ & $4729 \pm 259^{* *}$ \\
\hline \multicolumn{4}{|l|}{ Neural cell content } \\
\hline Pyramis & $1719 \pm 110$ & $1470 \pm 173$ & $3971 \pm 237^{* *}$ \\
\hline Cerebellum & $18,436 \pm 1308$ & $14,106 \pm 1472$ & $38,158 \pm 2724^{* *}$ \\
\hline \multicolumn{4}{|l|}{ Internal granule } \\
\hline Granule cell concentration, pyramis & $19,721 \pm 852$ & $17,673 \pm 362$ & $16,499 \pm 787$ \\
\hline \multicolumn{4}{|l|}{ Granule cell content } \\
\hline Pyramis & $8629 \pm 510$ & $6089 \pm 203^{* *}$ & $10,149 \pm 580^{*}$ \\
\hline Cerebellum & $103,317 \pm 4772$ & $74,572 \pm 2751^{* *}$ & $116,737 \pm 4832^{*}$ \\
\hline Granule/Purkinje cell ratio, pyramis & $186 \pm 12$ & $141 \pm 13^{* *}$ & $198 \pm 7$ \\
\hline Granule cell width $(\mu \mathrm{m})$, pyramis & $3.5 \pm 0.1$ & $3.3 \pm 0.1$ & $5.3 \pm 0.2^{* *}$ \\
\hline \multicolumn{4}{|l|}{ Medullary } \\
\hline Glia concentration, pyramis & $2315 \pm 115$ & $2555 \pm 164$ & $3395 \pm 142^{* *}$ \\
\hline \multicolumn{4}{|l|}{ Glia content } \\
\hline Pyramis & $190 \pm 23$ & $153 \pm 164$ & $294 \pm 35^{*}$ \\
\hline Cerebellum & $2534 \pm 313$ & $1988 \pm 207$ & $5229 \pm 403^{* *}$ \\
\hline
\end{tabular}

Values indicate means \pm SEM. Concentrations $=$ cells $/ \mathrm{mm}^{2}$; content $=$ cells $/$ section. Asterisks indicate significant difference from controls at $p<0.05\left(^{*}\right)$ or $p<0.01\left(^{* *}\right)$.

In order to fully define the effects of naltrexone administration on cell number, size, and distribution, we chose to examine one cerebellar lobe: the pyramis. To secure this profile, morphometric analysis of the pyramis was conducted; the data are presented in Figure 4. The results indicate a pattern of changes in the pyramis for the 1 and $50 \mathrm{mg} / \mathrm{kg}$ naltrexone groups resembling that found in the entire cerebellum (compare Figs. 2 and 4). The total area of the pyramis, as well as the areas of the MOL and IGL, were significantly increased $(25,24$, and $31 \%$, respectively) in rats of the $50 \mathrm{mg} / \mathrm{kg}$ group, but marked reductions $(31,35$, and $21 \%$, respectively) were recorded in animals of the $1 \mathrm{mg} / \mathrm{kg}$ group. The MED layers of rats from both naltrexone treatment regimens were similar to controls. In addition to areal measurements, a number of other parameters in the pyramis were evaluated. No significant change occurred in the width of the MOL for animals given $1 \mathrm{mg} / \mathrm{kg}$ naltrexone; however, this dimension was significantly $(p<0.01)$ increased $(21 \%)$ in rats of the $50 \mathrm{mg} / \mathrm{kg}$ naltrexone group. Measurements of the extent (length) of the Purkinje cell layer of the pyramis (controls $=4.16 \pm 0.34 \mathrm{~mm})$ were subnormal $(12 \%)$ for rats of the $1 \mathrm{mg} / \mathrm{kg}$ naltrexone group and increased $(20 \%)$ in animals of the $50 \mathrm{mg} / \mathrm{kg}$ naltrexone group; these changes were significant $(p<0.05)$.

\section{Quantitative analysis of cell number, size, and distribution}

The results of quantitative analysis of cell number, size, and distribution in the pyramis, and in some cases extrapolation to the entire section of the cerebellum, are presented in Table 1.

\section{Molecular layer}

The concentration of neural cells in the MOL of the pyramidal lobe, the vast majority of which were considered to be basket and stellate neurons, was comparable between the $1 \mathrm{mg} / \mathrm{kg}$ naltrexone-treated and control subjects. However, rats of the 50 $\mathrm{mg} / \mathrm{kg}$ naltrexone group had $80 \%$ more neural cells than controls in the pyramis. Computation of neural cell content in the pyramidal lobe revealed a subnormal number of cells $(43 \% ; p<$
0.05 ) in male rats of the $1 \mathrm{mg} / \mathrm{kg}$ group, but was not altered significantly when data for males and females were combined for analysis. Neural cell content was increased $131 \%$ for rats in the $50 \mathrm{mg} / \mathrm{kg}$ naltrexone group. Extrapolation to an entire section of the cerebellum revealed decreases (but not significant) in MOL cells of animals in the $1 \mathrm{mg} / \mathrm{kg}$ group, whereas rats in the $50 \mathrm{mg} / \mathrm{kg}$ group had more than twice the number of cells as control subjects $(p<0.01)$.

\section{Purkinje cell layer}

Little change in parameters related to Purkinje cells in the pyramis were detected in naltrexone-treated animals. Purkinje cell content, width, and packing density of both naltrexone-treated groups were comparable to control lcvels. In contrast to controls, a $32 \%$ increase $(p<0.01)$ in Purkinje cell dendritic domain was noted for rats of the $50 \mathrm{mg} / \mathrm{kg}$ naltrexone group, reflecting increased areal dimensions of the MOL.

\section{Internal granule layer}

The concentration of internal granule cells in the pyramis was comparable between control animals and those given naltrexone. Estimations of internal granule cell content in the pyramis revealed a decrease of $29 \%$ for rats in the $1 \mathrm{mg} / \mathrm{kg}$ naltrexone group and an $18 \%$ increase in $50 \mathrm{mg} / \mathrm{kg}$ treated animals. In a section of the entire cerebellum, there was a $28 \%$ decrease in the number of internal granule cells for the $1 \mathrm{mg} / \mathrm{kg}$ naltrexone group, whereas this measure was increased $13 \%$ in rats of the $50 \mathrm{mg} / \mathrm{kg}$ group; these alterations were statistically significant. Calculation of the ratio of internal granule neurons to Purkinje neurons in the pyramis revealed a $24 \%$ decrease in rats given 1 $\mathrm{mg} / \mathrm{kg}$ naltrexone. Measurements of internal granule cell diameter did not differ between control rats and those in the 1 $\mathrm{mg} / \mathrm{kg}$ naltrexone group, but granule cell diameter was about $50 \%$ greater in rats subjected to $50 \mathrm{mg} / \mathrm{kg}$ naltrexone.

\section{Medullary layer}

Concentrations of glial cells (i.e., oligodendrocytes and astrocytes) in the MED layer of the pyramis were markedly elevated 


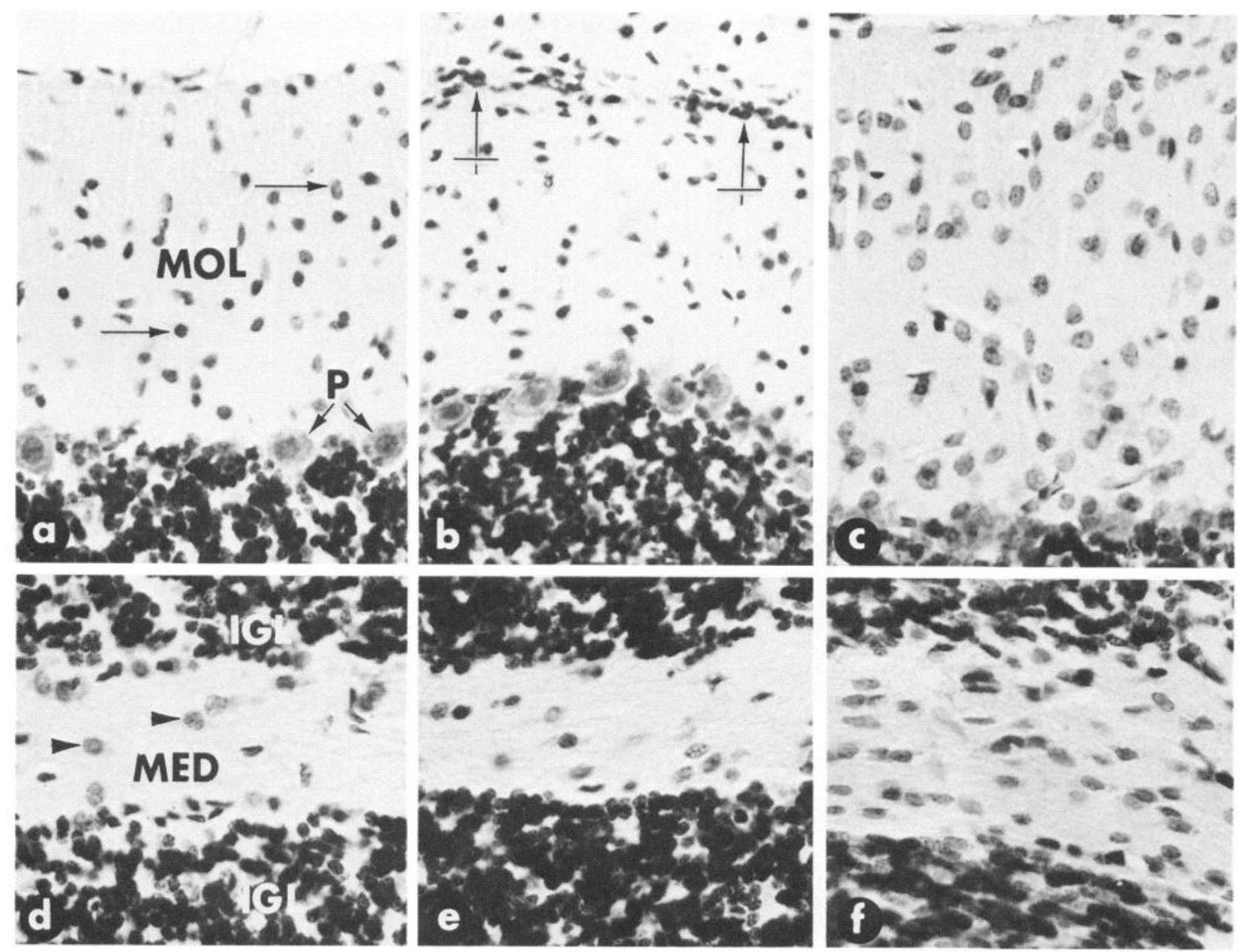

Figure 5. Histological comparison of sagittal sections of the cerebellar cortex (lobule VIII) from 21-d-old rats of the control $(a, d), 1 \mathrm{mg} / \mathrm{kg}(b$, $e$ ), and $50 \mathrm{mg} / \mathrm{kg}(c, f)$ naltrexone-treated groups. In $a-c$, note the differences in the size of the molecular layer (MOL) between groups and the extraordinary increase in neural cell number and size (arrows) in the $50 \mathrm{mg} / \mathrm{kg}$ naltrexone group $(c)$ as compared to the control $(a)$ and $1 \mathrm{mg} /$ $\mathrm{kg}$ naltrexone $(b)$ groups. Remnants of the external germinal layer (cross-hatched arrows) can be observed in the $1 \mathrm{mg} / \mathrm{kg}$ naltrexone group $(b)$. $P$, Purkinje cells. Photomicrographs $d-f$ are of the medullary layer $(M E D)$ and internal granule layers $(I G L)$ of control $(d)$ and naltrexone-treated groups $(e, f)$. A notable increase in the number of glial cells (arrowheads) was often recorded in animals of the $50 \mathrm{mg} / \mathrm{kg}$ naltrexone group $(f)$. $\times 425$.

$(47 \%)$ in rats of the $50 \mathrm{mg} / \mathrm{kg}$ naltrexone group but were similar to control values for animals in the $1 \mathrm{mg} / \mathrm{kg}$ naltrexone group. Glial cell content in the pyramis was subnormal (19\%) in animals of the $1 \mathrm{mg} / \mathrm{kg}$ group but $54 \%$ greater than controls for rats in the $50 \mathrm{mg} / \mathrm{kg}$ group; only the difference between control and $50 \mathrm{mg} / \mathrm{kg}$ animals was statistically reliable $(p<0.05)$. In the MED layer, for the entire cerebellum, the $1 \mathrm{mg} / \mathrm{kg}$ group had a $21 \%$ decrease in glial cell content, but this reduction from control levels was not significant. However, glial cell content in the entire cerebellum for males in this group was decreased by $36 \%$, and this was statistically significant $(p<0.05)$. Animals in the $50 \mathrm{mg} / \mathrm{kg}$ naltrexone group had $105 \%$ more glial cells in the MED layer of the entire cerebellum than controls.

\section{Histology}

Representative images of histological and histochemical preparations are presented in Figures 5-8. The overall architecture of the cerebellum at $21 \mathrm{~d}$ was generally similar in naltrexonetreated and control groups. Some remnants of the external germinal layer were observed in the $1 \mathrm{mg} / \mathrm{kg}$ naltrexone and control groups. A reduction in the MOL of the $1 \mathrm{mg} / \mathrm{kg}$ group, in contrast to control animals, was often evident (compare Fig. 5, $a$ and $b$ ). Also quite notable was a marked increase in MOL width, cell number, and cell size in cerebellar sections of $50 \mathrm{mg} / \mathrm{kg}$ nal- trexone-treated rats in contrast to control subjects (compare Fig. $5, a$ and $c$ ). An abnormal increase in glial cells was often noted in the MED layer of cerebella from $50 \mathrm{mg} / \mathrm{kg}$ naltrexone animals (Fig. 5f); however, these cells were often arranged in groupings rather than the more evenly dispersed pattern found in control and $1 \mathrm{mg} / \mathrm{kg}$ naltrexone animals.

Profiles of specimens stained with protargol silver were extremely revealing in regard to cerebellar ontogeny (Figs. 6-8). In control animals, some silver-stained processes oriented perpendicular to the long axis of the cerebellum were noted in the lower half of the MOL along with argyrophilic strands that encapsulated the Purkinje cells (Fig. 6a). Thin, silver-stained processes were noted coursing in the MED (Fig. 7a), with some of these fibers extending into the IGL (Figs. $6 a, 7 a$ ). Neurons of the deep cerebellar nuclei exhibited a dense impregnation of the soma but little staining of the nuclear region, except for the nucleolus (Fig. 8a). In contrast to control specimens, rats subjected to $1 \mathrm{mg} / \mathrm{kg}$ naltrexone had very few fibers surrounding the Purkinje cells or in the MOL (Fig. $6 b$ ), as well as a noticeable reduction in argyrophilic strands in the MED (Fig. $7 b$ ). Although neurons of the deep cerebellar nuclei exhibited dense impregnation, the size of these cells, along with the amount of silverstained fibers surrounding these neurons, was subnormal (Fig. $8 b$ ). Observation of the $50 \mathrm{mg} / \mathrm{kg}$ naltrexone group revealed a 
cerebellar cortex that was remarkably different from control specimens (Figs. $6 c, 7 c, 8 c$ ). An extensive network of argyrophilic fibers was noted in the MOL, particularly in the more basal regions. Purkinje cells were encapsulated by numerous silver-stained processes. Distinct fibers of varying diameter and length were noted coursing through the IGL (Figs. $6 c, 7 c$ ). The MED contained numerous argyrophilic fibers that were generally of a greater diameter than those of control rats (Figs. $6 c$, $7 c$ ). Deep cerebellar neurons (Fig. $8 c$ ) often appeared to be larger than those in sections of control specimens, and the argyrophilia of these neurons was of a more dispersed quality than seen in control subjects. The number of silver-stained fibers surrounding these neurons was often noticeably greater than those in cerebella of control rats.

\section{Discussion}

The results of this study extend our earlier observations (Zagon and McLaughlin, 1983b) and demonstrate that opioid antagonists exert a remarkable effect on cerebellar development in the rat. At a drug dosage that is known to block opioid receptors for the entire day, i.e., $50 \mathrm{mg} / \mathrm{kg}$ (Zagon and McLaughlin, 1983b, 1984), naltrexone has a stimulatory action on cerebellar development. Naltrexone has an inhibitory effect on cerebellar growth at a drug dosage that is known to block opioid receptors temporarily each day $(1 \mathrm{mg} / \mathrm{kg})$. Given the disappearance of the external germinal layer by $21 \mathrm{~d}$, the normal time for cessation of this layer (Altman, 1972), it appears that naltrexone does not alter the temporal course of preweaning neurogenesis. Rather, opioid antagonist action focuses on events (i.e., cell proliferation and differentiation) that transpire over the course of the first 3 postnatal weeks. It does appear that there are limits to naltrexone's ability to modulate cerebellar ontogeny, and that considerably more latitude exists toward growth enhancement than growth impairment. Alterations in macroscopic and areal dimensions were noted in both naltrexone-treated groups. However, in regard to cellular parameters, the $50 \mathrm{mg} / \mathrm{kg}$ group had many more changes, and generally of greater magnitude, than those that occurred in the $1 \mathrm{mg} / \mathrm{kg}$ group. Importantly, naltrexone affected both neurons and glia. Additionally, only those neural cells that were still in the midst of being generated (e.g., granule cells) were altered in regard to cell number. Cellular elements already derived prior to naltrexone treatment (e.g., Purkinje cells) were only capable of being influenced in terms of differentiative processes. Naltrexone also did not exert any specificity toward one sex in this study. It should be noted that the morphological changes registered in this study were monitored in $10 \mu \mathrm{m}$ sections. To obtain the full biological measure of naltrexone's effects, these data must be multiplied manyfold. Clearly, biochemical determinations of DNA, RNA, and protein will provide an even better perspective of naltrexone's influence on cerebellar development.

Given the marked alterations induced by naltrexone, an important question is whether these changes hold any functional significance for the developing animal. Information available on the maturation of physical and behavioral characteristics suggests that these morphological changes are of great importance in this regard (Zagon and McLaughlin, 1983c, 1985a). The appearance of such physical characteristics as hair covering, incisor eruption, ear opening, and eye opening were often delayed in the $1 \mathrm{mg} / \mathrm{kg}$ naltrexone group, and accelerated in animals subjected to $50 \mathrm{mg} / \mathrm{kg}$ naltrexone. Observations of the ontogeny of gross motor development and the maturation of

Figure 6. Protargol-stained sections of the cerebellar cortex from control $(a), 1 \mathrm{mg} / \mathrm{kg}(b)$, and $50 \mathrm{mg} / \mathrm{kg}(c)$ naltrexone-treated animals. In contrast to the control group, in which argyrophilic fibers (arrows) can be recorded in the molecular layer $(M O L)$, encompassing the Purkinje

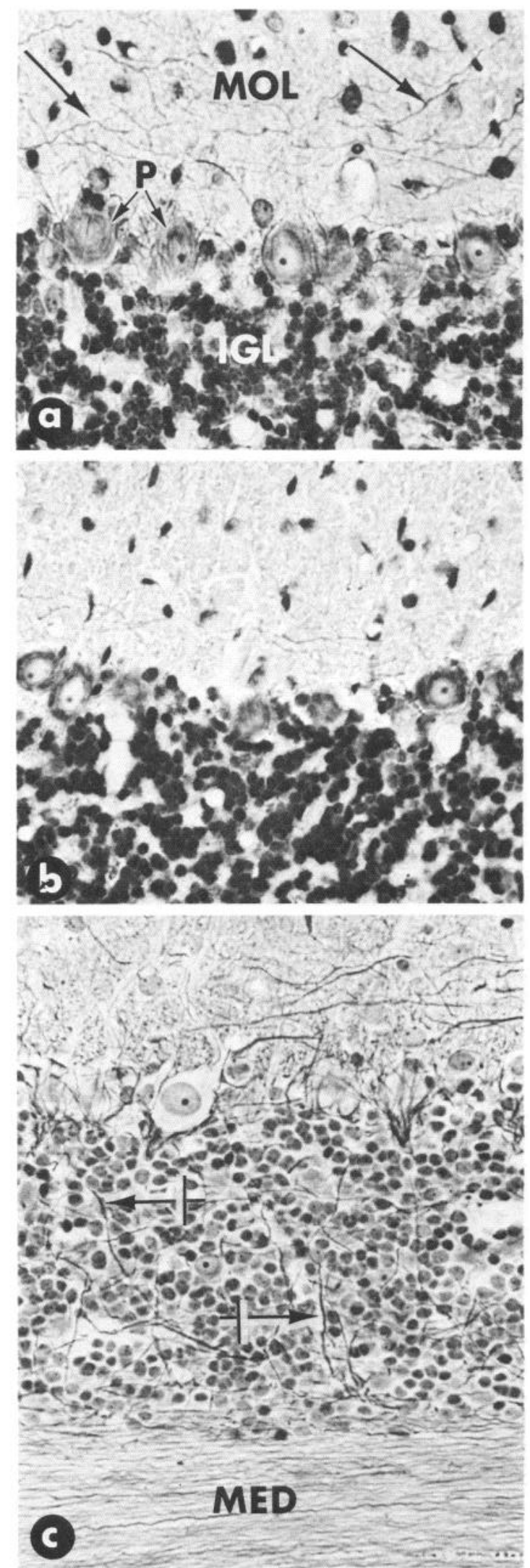

cells $(P)$, and the internal granule layer $(I G L)$, the $1 \mathrm{mg} / \mathrm{kg}$ naltrexone group demonstrated considerably less development. However, argyrophilic fibers were very apparent in the MOL of $50 \mathrm{mg} / \mathrm{kg}$ naltrexone rats. Unlike controls, nerve fibers coursing to and from the medullary layer $(M E D)$ were quite evident in sections from $50 \mathrm{mg} / \mathrm{kg}$ naltrexonetreated rats. $\times 390$. 

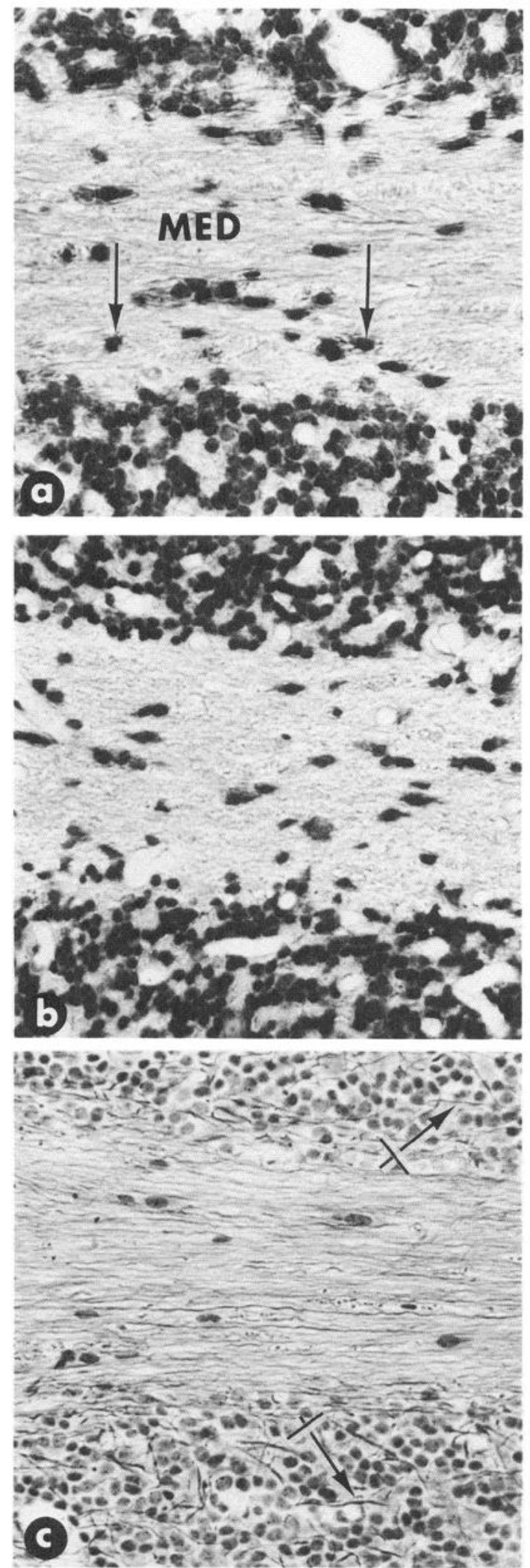

Figure 7. Protargol-stained preparations showing the medullary layer $(M E D)$ and internal granule layer $(I G L)$ of control $(a), 1 \mathrm{mg} / \mathrm{kg}(b)$, and $50 \mathrm{mg} / \mathrm{kg}(c)$ naltrexone-treated specimens. Arrows indicate glial cell nuclei impregnated with protargol silver. Nerve fibers (cross-hatched arrows) were evident in the internal granule layer of the $50 \mathrm{mg} / \mathrm{kg}$ naltrexone group but difficult to observe in section from control and 1 $\mathrm{mg} / \mathrm{kg}$ naltrexone-treated rats. In addition, argyrophilic fibers in the MED of the $50 \mathrm{mg} / \mathrm{kg}$ naltrexone group were often more numerous and of larger caliber than in other groups. $\times 390$.
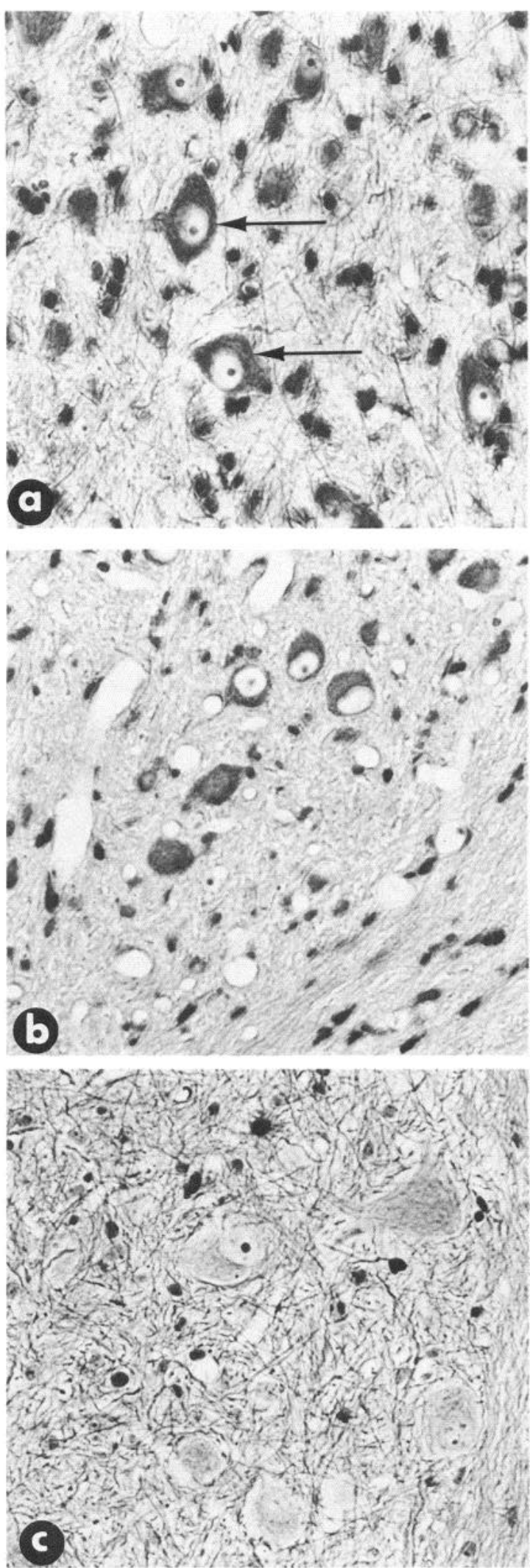

Figure 8. Deep cerebellar nuclei of control $(a), 1 \mathrm{mg} / \mathrm{kg}(b)$, and 50 $\mathrm{mg} / \mathrm{kg}(c)$ naltrexone-treated animals stained with protargol. In comparison to controls, nerve fibers were often more discrete in definition, and neuronal soma larger and less argyrophilic in specimens of the 50 $\mathrm{mg} / \mathrm{kg}$ naltrexone group; nerve fibers were often less visible and neuronal size diminished in sections of the $1 \mathrm{mg} / \mathrm{kg}$ naltrexone-treated group. $\times 400$. 
both simple and complex sensory motor behaviors showed a similar pattern of response. However, naltrexone's actions were restricted to certain modalities, since, in general, activity, emotionality, and nociceptive response were unaltered by drug treatment.

The specific mechanisms as to how naltrexone regulates growth have yet to be determined. The dosages needed to alter cerebellar ontogeny are exceedingly low, being $0.05-2.5 \%$ of the LD50 in adult rats (Braude and Morrison, 1976). It does not appear that naltrexone's effects are a reflection of nutritional status, nor are hormonal changes believed to be responsible for naltrexone's actions on development (Zagon and McLaughlin, 1984), although further studies are being conducted to evaluate this possibility. Naltrexone's influence on growth has been shown to depend on its pharmacological activity to block the opioid receptor (Zagon and McLaughlin, 1984). In regard to the cerebellum, some information is available on the ontogeny of opioid receptors and endogenous opioids. ${ }^{3} \mathrm{H}$-methionine enkephalin and ${ }^{3} \mathrm{H}$-naloxone receptor binding has been detected in developing cerebellum (Tsang and $\mathrm{Ng}, 1980$; Tsang et al., 1982a, b), with the highest levels recorded within the first few days of life and declining to low levels shortly thereafter. $\beta$-Endorphin and enkephalin levels in the cerebellum were also found to reach their highest levels in the first postpartum week and to decline subsequently to low levels (Maseda et al., 1983; Tsang et al., 1982b). Recently, the distribution of enkephalin in the cerebellum was examined by immunocytochemistry (Zagon et al., 1985). Methionine and leucine enkephalin were found to be concentrated in the external germinal cells of 10 -d-old rat cerebellum and was localized throughout the cortical cytoplasm. Enkephalin was not detected by immunocytochemistry in differentiated neural cells originating from this layer (e.g., internal granule neurons). Results from these studies indicate that endogenous opioids are involved specifically in development and bear a special relationship to cell proliferation and differentiation. The present data show that neuro-ontogeny can be dramatically altered by perturbation of endogenous opioid-opioid receptor interactions, further indicating that endogenous opioid systems play a crucial role in developmental events.

At this time, it would appear that endogenous opioids serve to control growth through interaction with the opioid receptor. We now can clearly observe that these effects are localized to cellular events related to proliferation and differentiation. Complete prevention of endogenous opioid-opioid receptor interaction by administration of relatively high dosages of naltrexone once daily as in the present study, or low dosages of naltrexone given repcatedly cach day (Zagon and McLaughlin, 1984), allows growth to proceed in a relatively "unimpeded" fashion. This would suggest that endogenous opioids play a critical part as natural trophic factors in growth, serving to regulate ontogenic events through inhibitory mechanisms. The type(s) of endogenous opioid(s) involved, as well as the specific opioid receptor(s) mediating development, is unknown. It seems that enhancement of endogenous opioid-opioid receptor interaction, such as that recorded with temporary opioid receptor blockade by appropriate dosages of naltrexone, inhibits some aspects of cell growth. Although the reasons for this diminution of growth have yet to be elucidated, naltrexone administration in early life has been reported to increase opioid receptor binding (Bardo et al., 1983) and to produce a supersensitivity to opioid agonists (Bardo et al., 1983). Moreover, naltrexone administration has been reported to elevate plasma $\beta$-endorphin levels (Recant et al., 1980). Therefore, it may be conjectured that in contrast to a total blockade of endogenous opioid-opioid receptor interaction, a temporary blockade provides an interval each day when the inhibitory action of basal or even elevated levels of endogenous opioids can act on cells possessing a greater complement of opioid receptors. This would also be consistent with studies in our laboratory (I. S. Zagon and P. J. McLaughlin, unpublished observations) and others (Vertes et al., 1982) that endogenous opioids inhibit mitosis and DNA synthesis in the developing brain, but opioid antagonist administration (in specific regimens) enhances cell proliferation. Thus, evidence gathered in this and other studies reveals seemingly different, yet complementary, faces to one fundamental process: growth regulation by endogenous opioid systems. If endogenous opioids do act by inhibiting growth through the opioid receptor, then administration of exogenous opioids during the perinatal period could have a similar action. Indeed, exogenous opioids such as heroin, methadone, and morphine disturb the growth of humans, laboratory animals, and cultured cells (McLaughlin and Zagon, 1984; Slotkin et al., 1980; Smith et al., 1977; also see reviews by 7agon et al., 1982, 1984); in laboratory studies, these effects are reversed by naloxone and are stereospecific. In this regard, it is important to note that macroscopic, histological, and neurochemical studies have shown that the developing cerebellum is extremely sensitive to opioid agonist actions (Zagon and McLaughlin, 1977, 1978, 1982). Fascinatingly, studies of endogenous opioids may provide valuable clues in unraveling the mechanisms involved in perinatal opioid exposure.

\section{References}

Altman, J. (1972) Postnatal development of the cerebellar cortex in the rat. I. The external germinal layer and the transitional molecular layer. J. Comp. Neurol. 145: 353-398.

Bardo, M. T., R. K. Bhatnagar, and G. F. Gebhart (1983) Age-related differences in the effect of chronic administration of naloxone on opiate binding in rat brain. Neuropharmacology 22:453-461.

Barnes, D., and J. Altman (1973) Effects of two levels of gestationlactational undernutrition on the postweaning growth of the rat cerebellum. Exp. Neurol. 38: 420-428.

Bauer-Moffett, C., and J. Altman (1977) The effect of ethanol chronically administered to preweanling rats on cerebellar development: A morphological study. Brain Res. 119: 249-268.

Braude, M. C., and J. M. Morrison (1976) Preclinical toxicity studies of naltrexone. NIDA Res. Monogr. 9: 16-26.

Maseda, C., E. G. Aguado, M. A. Mena, and J. G. De Yevenes (1983) Ontogenetic development of $\beta$-endorphin immunoreactivity in rat brain regions. Neurosci. Lett. Suppl. 14: 2237 .

McLaughlin, P. J., and I. S. Zagon (1984) Opioid regulation of neurotumor cell growth in vitro. Soc. Neurosci. Abstr. 10: 1111.

Nicholson, J. L., and J. Altman (1972) The effects of early hypo- and hyper-thyroidism on the development of the rat cerebellar cortex: I. Cell proliferation and differentiation. Brain Res. 44: 13-23.

Recant, L., N. R. Voyles, M. Luciano, and C. B. Pert (1980) Naltrexone reduces weight gain, alters " $\beta$-endorphin," and reduces insulin output from pancreatic islets of genetically obese mice. Peptides 1: 309-313.

Slotkin, T. A., F. J. Seidler, and W. L. Whitmore (1980) Effects of maternal methadone administration on ornithine decarboxylase in brain and heart of the offspring: Relationships of enzyme activity to dose and to growth impairment in the rat. Life Sci. 26: 861-867.

Smith, A. A., F. W. Hui, and M. J. Crofford (1977) Inhibition of growth in young mice treated with d,l-methadone. Eur. J. Pharmacol. 43: $307-314$

Tsang, D., and S. C. Ng (1980) Effect of antenatal exposure to opiates on the development of opiate receptors in rat brain. Brain Res. 188 . 199-206.

Tsang, D., S. C. Ng, and K. P. Ho (1982a) Development of methionineenkephalin and naloxone binding sites in regions of rat brain. Dev. Brain Res. 3: 637-644.

Tsang, D., S. C. Ng, K. P. Ho, and W. K. K. Ho (1982b) Ontogenesis of opiate binding sites and radioimmunoassayable $\beta$-endorphin and enkephalin in regions of rat brain. Dev. Brain Res. 5: 257-261.

Vertes, Z., G. Melegh, M. Vertes, and S. Kovacs (1982) Effect of naloxone and D-met ${ }^{2}$-pros ${ }^{5}$-enkephalinamide treatment on the DNA synthesis in the developing rat brain. Life Sci. 31:119-126.

Wilson, C. S. (1975) Somatic growth effects of perinatal addiction. Addict. Dis. 2: 333-345.

Zagon, I. S., and R. S. Lasher (1977) A modification of the Bodian technique for embedded, frozen, and cultured nervous tissue. Trans. Am. Microsc. Soc. 96: 91-97.

Zagon, I. S., and P. J. McLaughlin (1977) The effects of different 
schedules of methadone treatment on rat brain development. Exp. Neurol. 56: 538-552.

Zagon, I. S., and P. J. McLaughlin (1978) Perinatal methadone exposure and brain development: A biochemical study. J. Neurochem. 31: 49-54.

Zagon, I. S., and P. J. McLaughlin (1979) Morphological identification and biochemical characterization of isolated brain cell nuclei from the developing rat cerebellum. Brain Res. 170: 443-457.

Zagon, I. S., and P. J. McLaughlin (1982) Neuronal cell deficits following maternal exposure to methadone in rats. Experientia 38: 1214 1216.

Zagon, I. S., and P. J. McLaughlin (1983a) Naltrexone modulates tumor response in mice with neuroblastoma. Science 221: 671-673.

Zagon, I. S., and P. J. McLaughlin (1983b) Increased brain size and cellular content in infant rats treated with an opiate antagonist. Science 221: 1179-1180.

Zagon, I. S., and P. J. McLaughlin (1983c) Naltrexone modulates growth in infant rats. Life Sci. 33: 2449-2454.

Zagon, I. S., and P. J. McLaughlin (1984) Naltrexone modulates body and brain development in rats: A role for endogenous opioids in growth. Life Sci. 35: 2057-2064.

Zagon, I. S., and P. J. McLaughlin (1985a) Naltrexone's influence on neurobehavioral development. Pharmacol. Biochem. Behav. 22:441448.

Zagon, I. S., and P. J. McLaughlin (1985b) Opioid antagonist-induced regulation of organ development. Physiol. Behav. 34: 507-511.

Zagon, I. S., and P. J. McLaughlin (1985c) Stereospecific modulation of tumorigenic response by opioid antagonists. Eur. J. Pharmacol. 113: 115-120.

Zagon, I. S., P. J. McLaughlin, D. J. Weaver, and E. Zagon (1982) Opiates, endorphins, and the developing organism: A comprehensivc bibliography. Neurosci. Biobehav. Rev. 6: 439-479.

Zagon, I. S., P. J. McLaughlin, and E. Zagon (1984) Opiates, endorphins, and the developing organism: A comprehensive bibliography, 1982-1983. Neurosci. Biobehav. Rev. 8: 387-403.

Zagon, I. S., R. E. Rhodes, and P. J. McLaughlin (1985) Localization of enkephalin immunoreactivity in germinative cells of developing rat cerebellum. Science 227: 1049-1051. 